\title{
Prioritizing Sustenance of Village Ponds for Avian Conservation: A Case Study from Punjab, India
}

\author{
Sukhpreet Kaur Sidhu*, Gurkirat Singh Sekhon, Randeep Kaur Aulakh and \\ Tejdeep Kaur Kler
}

Department of Zoology, Punjab Agricultural University, Ludhiana, 141004

\begin{abstract}
A B S T R A C T
Ponds in farmlands are an integral component of the hydrological system; and perform diverse roles in the biosphere. The present study on ponds was carried out on avian diversity and its services of composition in relation to vegetation distribution to understand their biodiversity. Four natural ponds and one manmade pond were surveyed at three locations viz. Ludhiana (location I), Ropar (location II) and Ferozpur (location III) falling in three agro climatic zones. A total of 51 bird species belonging to 31 families and 15 orders were recorded from studied locations. A diverse range of vegetation distribution was observed with 12 weed species, 22 tree species and three crops near the ponds. Avian species richness index was found positively correlated high with the occurrence of bird species in the habitat, rather than their individuals. The results of this study indicated that vegetation complexity in pond surroundings influenced the abundance and number of water dependent and terrestrial bird species directly and indirectly in agricultural habitats.
\end{abstract}
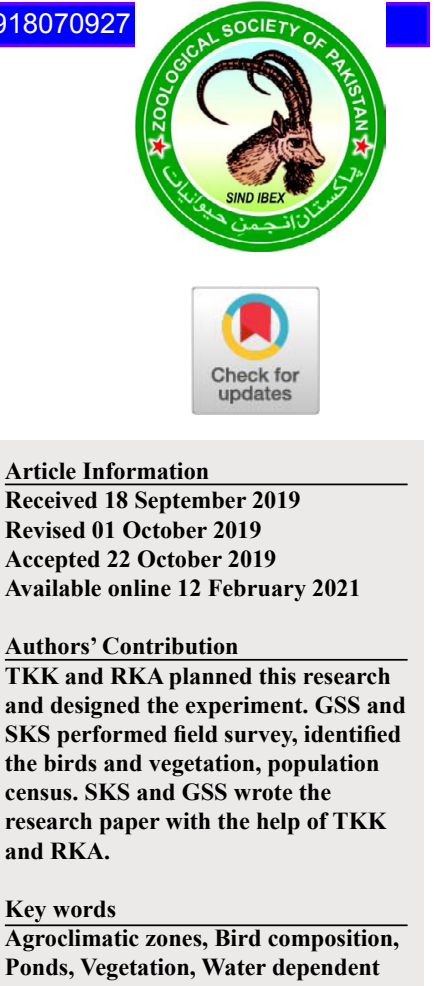

\section{INTRODUCTION}

$\mathrm{P}$ onds are common landscape elements which play important role in the global processes of biosphere and preservation of biodiversity (Miracle et al., 2010). The role of ponds in supporting aquatic biodiversity is just as important as rivers and large lakes. They provide unique habitat islands for a diverse range of aquatic species (Smith et al., 2002; Fairchild et al., 2005). It has been ascertained that ponds are important biodiversity hotspots both in relation to species composition and biological traits, and they play a significant role in providing ecosystem services (Cereghino et al., 2014). Farm ponds are key habitats for organisms, such as plants, insects, fish, amphibians, reptiles, birds, and mammals and can form complete ecosystems (Froneman et al., 2001; Huang, 2012). In an ecosystem, birds are higher vertebrates, and often play tertiary roles in the ecological pyramid. They provide functions for promoting the flow of energy and nutrient recycling of species and maintaining ecological balance between primary producers and consumers $(\mathrm{Lu}$ et al., 2007; Ma et al., 2010). However, birds are quite sensitive in regard to habitat selection to environmental conditions. Thus, when the habitat is damaged or altered, the birds' clustering characteristics change correspondingly

\footnotetext{
* Corresponding author: sukhsidhupau@gmail.com 0030-9923/2021/0002-0555 \$9.00/0

Copyright 2021 Zoological Society of Pakistan
}

(Chang and Chang, 2000). Since birds are numerous, and easy to observe, record, and quantify, they are useful and more accessible to study the functioning and structure of wildlife species in terms of ecological theory and habitat conservation practices (Ma et al., 2010). Also, several previous studies (Hunter et al., 2002; Sebastián-González, 2010) have chosen water birds as indicators to investigate the characteristics and planning of biological environments around artificial/semi-artificial ponds. Manoj and Padhy (2015) reviewed the scientific reports on large water bodies, especially rivers, have recently gained popularity in India. Literature survey, however, reveals very little investigative reports on disappearance of ponds in India. In the absence of any review work on pond environments it is hard to arrive scientifically at their current status in India. Pond resources, especially the dependent nature of faunal communities over the producers of floristic components are required to be monitored (Jha, 2013). Therefore, a survey for two consequent days in every month was carried out from March 2019 to July 2019, to assess the aquatic, terrestrial vegetation around the ponds and avian species diversity and composition in village (rural) ponds located in three agro climatic zones of Punjab.

\section{MATERIALS AND METHODS}

Study area

Three selected ponds in village Jhamat, village Malakpur and Punjab Agricultural University (PAU) 
campus named as pond $\mathrm{A}, \mathrm{B}$ and $\mathrm{C}$, respectively at location I (district Ludhiana) (latitude 30 $54^{\circ} 3.4740^{\prime \prime} \mathrm{N}$ and longitude $75^{\circ} 51^{\prime}$ '26.1972'E). In villages Mukrabpur (district Ropar) and Vaa (district Ferozpur), pond D and pond $\mathrm{E}$ were selected at location II (latitude $30^{\circ} 58^{\prime}$ $30.9144^{\prime \prime} \mathrm{N}$ and longitude $76^{\circ} 31^{\prime} 38.3808^{\prime \prime} \mathrm{E}$ ) and location III (latitude $30^{\circ} 55^{\prime} 24.3588^{\prime} \mathrm{N}$ and longitude $74^{\circ} 36^{\prime}$ 36.7704"E) respectively. Ponds A (area 2.5 acre) is located in the village Jhamat surrounded by residential houses. Pond B ( 3 acre), Pond D ( 2 acre) and Pond E ( 4 acre) are located near outskirts of the village having residential village houses on one side and agricultural fields adjoining the other side. Pond C ( 4 acre) is a man-made pond having treated water of sewage plant located near botanical garden and agricultural fields. All the studied ponds except pond $\mathrm{C}$ are natural ponds that remain filled throughout the year and fed by surface run flow and direct rainfall.

\section{Methodology/vegetation and bird diversity analysis}

The survey was conducted on vegetation and birds, from March 2019 to July 2019. Data were collected for two consequent days every month. During each survey, both the aquatic and the dry benthic surface vegetation was noted down. Data on bird diversity and composition were collected in the morning between 5.00-8.00 am and in the evening between 5.00-6.30 pm. All out search method was used in the enumeration of vegetation. Survey was conducted by walking on existing trails and track using the knowledge of standard field guides (Grimmett et al., 2011). Bird population was estimated employing Point Count Protocol (Verner, 1985), using Nikon action 16x50x4.1 zooming binocular and photographic documentation was made. The checklist of species was prepared following the nomenclature of (Parveen et al., 2016). The data collected were used to compute Shannon-Wieners index. Shannon index reflects both species richness and evenness of distribution among species present (Nur et al., 1999). Species richness index was calculated for every month, using the following equation:

$$
\text { Species richness index }=\frac{\text { Total number of species }}{\log (\text { total number of individuals })}
$$

\section{Statistical analysis}

Regression analysis was performed to correlate the species richness index with total number of avian species and total number of individuals.

\section{RESULTS AND DISCUSSION}

Survey record revealed the occurrence of 51 bird species belonging to 31 families and 15 orders from studied locations during the study period (Table I). Of
51 bird species 45 species are resident and six (6) are migratory bird species. Fourteen bird species are water dependent and 37 are terrestrial bird species. Mohan and Gaur (2008) reported 62 bird species belonging to 15 orders and 26 families at Jajiwal pond of Jodhpur city. Vegetation diversity of ponds consisted of 22 tree species, 11 weeds (both forbs and grasses) and four (4) cereal, fodder and vegetable crops (Table II). These results are supported by the study on the habitat of ponds possessing rich vegetation diversity by Sleeter et al. (2013).

Species richness index was the highest (5.26) in the month of March at pond B and lowest (2.40) in the month of April at pond A (Table III).

At pond A, 29 bird species were recorded (Table I); 9 water dependent and 20 terrestrial bird species. Blue Rock Pigeon (36.94\%) was recorded as the most abundant species in large flocks. They were observed roosting on the roofs of religious places and community centres located in close vicinity of the pond. Indian moorhen (13.76\%) was the second most abundant bird species followed by common myna $(9.60 \%)$ and white-breasted waterhen (4.35\%). Anthropogenic activities due to surrounding human habitation affected the abundance of water bird species (Kumar et al., 2016). Yellow-legged green pigeon was exclusively found at pond A, its presence could be correlated with banyan Ficus benghalensis and peepal Ficus religiosa trees. Abundance of spot-billed duck was high in the month of May $(9.72 \%)$ with small chicks swimming along the floating weed morning glory Ipomoea carnea and Ipomoea nil. Chicks of Indian moorhen were observed in the month of April and May near the dense vegetation of elephant grass Pennisetum purpureum and nadi grass Dicanthium caricosum submerged in the pond. White-breasted waterhen was also observed collecting the nesting material in the month of July.

A total of 36 bird species were present at Pond B; 13 water dependent and 23 terrestrial. Species richness of water dependent bird species at this pond was the highest of all the other ponds. Indian moorhen was recorded as the most abundant bird species with $16.66 \%$ abundance followed by common swallow $(10.73 \%)$ and blue rock pigeon $(8.83 \%)$. Chicks of Indian moorhen were observed in the pond from the month of April, May and June; sometimes hiding in the weeds growing along the bank e.g. cannabis Cannabis sativa, congress grass Parthenium hysterophorus and elephant grass Pennisetum purpureum. Presence of maximum number of weed vegetation, agricultural fields and heaps of cattle dung along one side of the pond provided the abundant food (aquatic and terrestrial insects, small invertebrates and vertebrates) for waders and mud probing bird species. Mahesh et al. (2018) had also observed the water birds feeding on edges 
Table I. List of relative abundance (\%) of bird species observed at location I, II and III.

\begin{tabular}{|c|c|c|c|c|c|c|}
\hline \multirow[t]{2}{*}{ S. No. Birds (Scientific names) } & \multirow{2}{*}{$\begin{array}{l}\text { Migratory } \\
\text { status }\end{array}$} & \multicolumn{3}{|c|}{ Location I } & \multicolumn{2}{|c|}{ Location II Location III } \\
\hline & & Pond A & Pond B & Pond C & Pond D & Pond E \\
\hline \multicolumn{7}{|l|}{ Order: Passeriformes } \\
\hline \multicolumn{7}{|l|}{ Family: Sturnidae } \\
\hline 1 Common myna (Acridotheres tristis) & $\mathrm{R}$ & 9.60 & 6.81 & 9.66 & 11.20 & 14.16 \\
\hline 2 Asian pied starling (Sturnus contra) & $\mathrm{R}$ & 2.08 & 0.19 & - & 3.28 & - \\
\hline 3 Bank myna (Acridotheres ginginianus) & $\mathrm{R}$ & - & 1.55 & - & - & - \\
\hline \multicolumn{7}{|l|}{ Family: Hirundinidae } \\
\hline 4 Common swallow (Hirundo rustica) & M & 2.00 & 10.73 & - & 1.40 & - \\
\hline 5 Wire-tailed swallow (Hirundo smithii) & M & 1.92 & 4.59 & - & 1.58 & - \\
\hline \multicolumn{7}{|l|}{ Family: Pycnonotidae } \\
\hline 6 Red-vented bulbul (Pycnonotus cafer) & $\mathrm{R}$ & 1.45 & - & 2.91 & 1.20 & - \\
\hline \multicolumn{7}{|l|}{ Family: Muscicapidae } \\
\hline 7 Indian robin (Saxicoloides fulicatus) & $\mathrm{R}$ & 0.12 & 1.68 & - & 0.52 & - \\
\hline Brown rock chat (Cercomela fusca) & $\mathrm{R}$ & - & 0.48 & - & 2.12 & - \\
\hline \multicolumn{7}{|l|}{ Family: Motacillidae } \\
\hline $9 \quad$ White wagtail (Motacilla alba) & M & - & 0.29 & 1.63 & - & - \\
\hline 10 Large pied wagtail (Motacilla maderaspatensis) & $\mathrm{R}$ & - & 0.09 & 0.41 & - & - \\
\hline \multicolumn{7}{|l|}{ Family: Estrildidae } \\
\hline 11 Spotted munia (Lonchura puctulata) & $\mathrm{R}$ & 0.66 & 1.80 & - & - & - \\
\hline \multicolumn{7}{|l|}{ Family: Dicruridae } \\
\hline 12 Black drongo (Dicrurus adsimilis) & $\mathrm{R}$ & - & 0.89 & 0.85 & 0.63 & - \\
\hline \multicolumn{7}{|l|}{ Family: Passeridae } \\
\hline 13 House sparrow (Passer domesticus) & $\mathrm{R}$ & - & 1.02 & - & - & - \\
\hline \multicolumn{7}{|l|}{ Family: Corvidae } \\
\hline 14 House crow (Corvus splendens) & $\mathrm{R}$ & 5.22 & 4.67 & 6.58 & 10.18 & 13.94 \\
\hline 15 Indian treepie (Dendrocitta vagabunda) & $\mathrm{R}$ & 0.12 & - & - & - & - \\
\hline \multicolumn{7}{|l|}{ Family: Cisticolidae } \\
\hline 16 Common tailorbird (Orthotomus sutorius) & $\mathrm{R}$ & 0.43 & - & - & - & - \\
\hline 17 Roufous-fronted warbler (Prinia buchanani) & $\mathrm{R}$ & - & 0.62 & - & - & - \\
\hline 18 Ashy prinia (Prinia socialis) & $\mathrm{R}$ & - & 0.14 & - & 0.63 & - \\
\hline \multicolumn{7}{|l|}{ Family: Leiothrichidae } \\
\hline 19 Jungle babbler (Turdoides striatus) & $\mathrm{R}$ & - & - & 0.97 & - & - \\
\hline \multicolumn{7}{|l|}{ Family: Ploceidae } \\
\hline 20 Baya weaver (Ploceus philippinus) & $\mathrm{R}$ & - & - & - & - & 2.36 \\
\hline \multicolumn{7}{|l|}{ Family: Apodidae } \\
\hline 21 House swift (Apus affinis) & $\mathrm{R}$ & - & 5.00 & - & - & - \\
\hline \multicolumn{7}{|l|}{ Family: Rhipiduridae } \\
\hline 22 White-browed fantail (Rhipidura aureola) & $\mathrm{R}$ & - & 0.75 & - & - & - \\
\hline \multicolumn{7}{|l|}{ Order: Gruiformes } \\
\hline \multicolumn{7}{|l|}{ Family: Rallidae } \\
\hline 23 White-breasted waterhen (Amaurornisp hoenicurus) & $\mathrm{R}$ & 4.35 & 3.23 & 4.48 & 9.59 & 4.85 \\
\hline Common moorhen (Gallinnula chloropus) & $\mathrm{R}$ & 13.76 & 16.66 & 9.14 & 5.03 & 4.28 \\
\hline 25 Purple moorhen (Porphyrio porphyrio) & $\mathrm{R}$ & - & 1.22 & - & - & - \\
\hline 26 Common coot (Fulica atra) & $\mathrm{R}$ & - & 0.31 & - & 4.36 & - \\
\hline Order: Charadriiformes & & & & & & \\
\hline Family: Recurvirostridae & & & & & & \\
\hline 27 Black-winged stilt (Himantopus himantopus) & M & 2.13 & 5.01 & 11.84 & - & 8.51 \\
\hline Family: Charadriidae & & & & & & \\
\hline
\end{tabular}




\begin{tabular}{|c|c|c|c|c|c|c|}
\hline \multirow[t]{2}{*}{ S. No. Birds (Scientific names) } & \multirow{2}{*}{$\begin{array}{l}\text { Migratory } \\
\text { status }\end{array}$} & \multicolumn{3}{|c|}{ Location I } & \multicolumn{2}{|c|}{ Location II Location III } \\
\hline & & Pond A & Pond B & Pond C & Pond D & Pond E \\
\hline $28 \quad$ Red-wattled lapwing (Vanellus indicus) & $\mathrm{R}$ & 1.41 & 3.47 & 8.10 & 4.28 & 8.58 \\
\hline \multicolumn{7}{|l|}{ Family: Scolopacidae } \\
\hline 29 Common sandpiper (Actitis hypoleucos) & M & 0.25 & 0.72 & 0.76 & - & - \\
\hline \multicolumn{7}{|l|}{ Order: Anseriformes } \\
\hline \multicolumn{7}{|l|}{ Family: Anatidae } \\
\hline $30 \quad$ Spot-billed duck (Anas poecilorhyncha) & $\mathrm{R}$ & 5.42 & 6.11 & 3.10 & - & 4.35 \\
\hline 31 Lesser-whistling duck (Dendrocygna javanica) & M & 1.67 & 1.51 & 2.59 & - & 8.30 \\
\hline \multicolumn{7}{|l|}{ Order: Columbiformes } \\
\hline \multicolumn{7}{|l|}{ Family: Columbidae } \\
\hline 32 Rock pigeon (Columba livia) & $\mathrm{R}$ & 36.94 & 8.83 & - & 4.59 & 1.56 \\
\hline Yellow- legged green pigeon (Treron phoenicoptera) & $\mathrm{R}$ & 2.00 & - & - & 0.71 & - \\
\hline 34 Eurasian collared-dove (Streptopelia decaocto) & $\mathrm{R}$ & 1.12 & 0.39 & 0.27 & 2.58 & 0.93 \\
\hline 35 Little brown dove (Spilopelia senegalensis) & $\mathrm{R}$ & - & - & 0.36 & - & - \\
\hline \multicolumn{7}{|l|}{ Order: Psittaciformes } \\
\hline \multicolumn{7}{|l|}{ Family: Psittacidae } \\
\hline 36 Rose-ringed parakeet (Psittacula krameri) & $\mathrm{R}$ & 2.33 & 0.88 & 8.66 & 4.68 & 5.49 \\
\hline \multicolumn{7}{|l|}{ Order: Pelecaniformes } \\
\hline \multicolumn{7}{|l|}{ Family: Ardeidae } \\
\hline 37 Cattle egret (Bubulcus ibis) & $\mathrm{R}$ & 0.90 & 0.66 & 1.96 & 10.67 & 12.84 \\
\hline 38 Indian pond heron (Ardeola grayii) & $\mathrm{R}$ & 0.25 & 0.62 & 2.32 & 15.47 & 4.45 \\
\hline \multicolumn{7}{|l|}{ Order: Podicipediformes } \\
\hline \multicolumn{7}{|l|}{ Family: Podicipedidae } \\
\hline 39 Little grebe (Tachybaptus ruficollis) & $\mathrm{R}$ & 1.15 & 3.54 & - & - & - \\
\hline \multicolumn{7}{|l|}{ Order: Cuculiformes } \\
\hline \multicolumn{7}{|l|}{ Family: Cuculidae } \\
\hline 40 Asian koel (Eudynamys scolopaceus) & $\mathrm{R}$ & 1.46 & - & 0.84 & 0.42 & - \\
\hline 41 Greater coucal (Centropus sinensis) & $\mathrm{R}$ & 0.14 & - & 0.77 & 1.29 & - \\
\hline \multicolumn{7}{|l|}{ Order: Bucerotiformes } \\
\hline \multicolumn{7}{|l|}{ Family: Bucerotidae } \\
\hline 42 Indian grey hornbill (Ocyceros birostris) & $\mathrm{R}$ & 0.11 & - & 0.42 & - & - \\
\hline Family: Upupidae & & & & & & \\
\hline 43 Common hoopoe (Upupa epops) & $\mathrm{R}$ & - & 0.60 & - & - & - \\
\hline Order: Piciformes & & & & & & \\
\hline Family: Megalaimidae & & & & & & \\
\hline 44 Brown-headed barbet (Megalaima zeylanica) & $\mathrm{R}$ & - & - & 0.16 & - & - \\
\hline Order: Coraciiformes & & & & & & \\
\hline Family: Meropidae & & & & & & \\
\hline 45 Small green bee-eater (Merops orientalis) & $\mathrm{R}$ & 0.55 & 3.65 & - & 2.85 & 2.96 \\
\hline Family: Alcedinidae & & & & & & \\
\hline 46 White-breasted kingfisher (Halcyon smyrnensis) & $\mathrm{R}$ & 0.26 & 0.58 & - & 0.23 & 1.22 \\
\hline 47 Lesser pied kingfisher (Ceryle rudis) & $\mathrm{R}$ & - & - & - & - & 1.12 \\
\hline Order: Galliformes & & & & & & \\
\hline Family: Phasianidae & & & & & & \\
\hline 48 Indian peafowl (Pavo cristatus) & $\mathrm{R}$ & - & - & 10.84 & - & - \\
\hline 49 Grey francolin (Francolinus pondicerianus) & $\mathrm{R}$ & - & - & 0.54 & - & - \\
\hline Order: Accipitriformes & & & & & & \\
\hline Family: Accipitridae & & & & & & \\
\hline $50 \quad$ Black kite (Milvus migrans) & $\mathrm{R}$ & - & - & 8.39 & - & - \\
\hline Order: Suliformes & & & & & & \\
\hline Family: Phalacrocoracidae & & & & & & \\
\hline 51 Little cormorant (Microcarbio niger) & $\mathrm{R}$ & - & 0.19 & 0.71 & - & - \\
\hline
\end{tabular}


Table II. List of trees, weeds and other crops at location I, II and III.

\begin{tabular}{|c|c|c|c|c|c|}
\hline \multirow[t]{2}{*}{ S. no. Plants(Scientific names) } & \multicolumn{3}{|c|}{ Location I } & Location II & Location III \\
\hline & $\begin{array}{l}\text { Pond A } \\
\text { (Jhamat) }\end{array}$ & $\begin{array}{l}\text { Pond B } \\
\text { (Malakpur) }\end{array}$ & $\begin{array}{l}\text { Pond C } \\
\text { (PAU ponds }\end{array}$ & $\begin{array}{l}\text { Pond D } \\
\text { (Mukrabpur) }\end{array}$ & $\begin{array}{l}\text { Pond E } \\
\text { (Vaa) }\end{array}$ \\
\hline
\end{tabular}

\section{Name of the trees}

1. Satpattiya (Alstonia scholaris)

2. Dhek (Melia azedarach)

3. Banyan (Ficus benghalensis)

4. Peepal (Ficus religiosa)

5. Bamboo (Bambusoidae)

6. Guava (Psidium guajava)

7. Pilkhan (Ficus virens)

8. Mulberry (Morus alba)

9. Kikar (Vachellia nilotica)

10. poplar (Populus deltoides)

11. Simbal (Bombax ceiba)

12. Sheesham (Dalbergia sissoo)

13. Lassura (Cordia obliqua)

14. Sarin (Albizia lebbek)

15. Neem (Azadirachta indica)

16. Eucalyptus (Eucalyptus globulus)

17. Silver Oak (Grevillea robusta)

18. Tun (Toona ciliata)

19. Date Palm (Phoenix dactylifera)

20. Papaya (Carica Papaya)

21. Teak (Tectona grandis)

22. Beri (Zizyphus mauritiana)

Name of the weeds

23. Bathu (Chenopodium album)

24. Bhang, Cannabis (Cannabis sativa)

25. Guinea grass (Megathyrsus maximus)

26. It Sit (Trianthema portulacastrum)

27. Jungli cholai (Amaranthus viridis)

28. Arind (Ricinus communis)

29. Pink morning glory or besharmi booti (Ipomoea carnea)

30. Japanese morning glory (Ipomoea nil)

31. Congress grass (Parthenium hysterophorus)

32. Dib, Elephant grass (Pennisetum purpureum)

33. Nadi grass (Dicanthium caricosum)

34. Wild Jantar (Sesbania bispinosa)

\section{Other crops}

35. Barseem (Trifolium alexandrinum)

36. Wheat (Triticum aestivum)

37. Paddy (Oryza sativa)

38. Sponge gourd (Luffa aegyptiaca) 
of the pond on aquatic floating submerged and emergent hydrophytes. Mishra et al. (2019) had studied the habitat utilization, foraging habitat and status of aquatic birds species as resident or migratory at Bakhira Bird Sanctuary, Uttar Pradesh. Spot-billed duck were observed flapping and raising their wings in water. Analysis showed a correlation between the maximum value of bird species richness and the number of water dependent bird species at pond $\mathrm{B}$ because of the habitat features like excessive growth of eight weed species (forbs and grasses) surrounded by water flooded paddy fields. Soni et al. (2019) reported that ponds having higher tree diversity and wild vegetation supported more bird species and population abundance by providing shelter and roosting sites to water and terrestrial birds.

Table III. Month wise species richness index at studied ponds from March 2019 to July 2019.

\begin{tabular}{llllll}
\hline Months $\rightarrow$ & March & April & May & June & July \\
\hline Ponds $\downarrow$ & \multicolumn{5}{c}{ Species richness index } \\
\hline Pond A & 3.94 & 2.40 & 2.61 & 3.31 & 4.06 \\
Pond B & 5.26 & 2.83 & 4.47 & 3.53 & 4.13 \\
Pond C & 4.22 & 2.43 & 4.04 & 3.33 & 2.45 \\
Pond D & 3.00 & 3.38 & 3.16 & 3.95 & 3.25 \\
Pond E & 2.88 & 3.36 & 2.47 & 2.82 & 3.22 \\
\hline
\end{tabular}

Eight water dependent and 19 terrestrial out of 27 bird species were observed at pond C. black-winged stilt $(11.84 \%)$, indian peafowl $(10.84 \%)$ and common myna $(9.66 \%)$ were recorded as first, second and third most abundant bird species respectively. Passeriformes order was the most abundant order followed by Charadriiformes, Gruiiformes, Pelecaniformes, Gallidormes, Anseriformes, Cuculiformes, Columbiformes, Psittaciformes, Suliformes, Bucerotiformes and Piciformes. Indian peafowl, grey francolin, common pariah kite, little brown dove and jungle babbler were observed exclusively at man-made pond C. Diverse and dense vegetation of trees like dhek Melia azedarach, poplar Populus deltoides, sheesham Dalbergia sissoo, peepal Ficus religiosa, simbal Bombax ceiba, lassura Cordia obliqua, sarin Albizia lebbek, silver oak Grevillea robusta, tun Toona ciliata and neem Azadirachta indica around the pond might be the reason of presence of these avian species belonging to different bird families/ orders and having different feeding habits (Table II). The presence of grey francolins (partridges) indicated a habitat with undisturbed and scrubbed vegetation. Abundance of little cormorant at pond $\mathrm{B}$ and $\mathrm{C}$ clearly depicted the aquatic life like fishes in studied ponds. Black-winged stilt was observed nesting on the submerged wall partition at pond $\mathrm{C}$ in the month of April. Females incubating the eggs and with small chicks were observed in the month of June. Diverse plant community played an important role for majority of migrating and wintering water birds as they utilized the vegetation for their different needs (MacroMendez et al., 2015; Mahesh et al., 2018).

Bird diversity of 24 bird species was found at Pond D; five water dependent and 19 terrestrial bird species. Indian pond heron $(15.47 \%)$, common myna $(11.20 \%)$ and cattle egret $(10.67 \%)$ were the three most abundant in bird species. Abundance of Indian pond heron and cattle egret was the maximum because of their nesting on the date palm Phoenix dactylifera and tun Toona ciliate trees respectively. Kumar et al. (2016) had observed cormorants, egrets, herons, storks, kites and kingfishers used trees at the banks of the ponds for roosting and nesting. The pond has the maximum tree diversity (11) but less dense weed vegetation but the heaps of cattle dung with the sparse vegetation present on the banks of the pond provided food and hiding space for a few water bird species like white-breasted waterhen, Indian moorhen, indian pond heron, white-breasted kingfisher and common coot. Kler (2002) reported little grebe, white-breasted waterhen, white-breaseted kingfisher, pond heron, Indian moorhen were the most common bird species inhabiting ponds/waterbodies of studied villages namely Dhalia, Gill, Mullanpur, Kadian and Nanakpurjagera falling in Ludhiana district, two villages Palkadim and Kangjagir of Jalandhar district and Nangal village of Moga district. Nesting of Indian moorhen was observed in vegetation at the base of kikar Vachellia nilotica tree present near the edge of the pond having submerged branches in the water. Lai et al. (2018) reported the farm pond habitat suitability for the common moorhen at Chiayi County, Taiwan. Indian moorhen along with white-breasted waterhen was observed feeding on sponge gourd vines Luffa aegyptiaca and Luffa acutangula, small vegetation and near the heaps near the banks of pond.

At pond E, seventeen bird species were observed, seven were water dependent and ten terrestrial bird species. Common myna was the most abundant bird species with $14.16 \%$ of relative abundance followed by house crow (13.94\%) and cattle egret (12.84\%). Red-wattled lapwing, black-winged stilt and lesser-whistling duck were other most abundant bird species with relative abundance percentage of $8.58 \%, 8.51 \%$ and $8.30 \%$ respectively. Similarly, Mohan and Gaur (2008) stated that the egret, heron, black-winged stilt, plover and red-wattled lapwing were the dominant species at Jajiwal pond of Jodhpur city. In present investigation, these species were observed feeding and foraging near the pond and in agricultural crop field (paddy) along one side of the pond. Pied kingfisher had been rarely seen in central Punjab. The pond E is a few 
kilometres away from canal network Rajasthan feeder and Ferozpur feeder (Harike headworks). Nest site of blackwinged stilt was observed on submerged cemented wall in the pond. Lesser-whistling ducks were observed dabbling and diving in the water. Courtship behaviour of dipping and raising in water by lesser-whistling duck was observed during the months of May and June. Chicks of blackwinged stilt and lesser-whistling duck were observed in the month of July. Moist soil in ditches and along edges is used for foraging and dry land for breeding (Rajpar and Zakaria, 2011).

Avian species richness index was found positively correlated high with the occurrence of bird species in the habitat, rather than their individuals.

\section{CONCLUSION}

Populations of fig specialist bird species like yellowlegged green pigeon may be sustained by preserving and planting the indigenous trees like banyan and peepal. Thirteen water dependent bird species belonging to diverse families/orders directly are dependent on rejuvenation of village ponds through community participation in farmlands. To sustain the aerial feeders like swallows and swifts, water habitats need to be kept clean of sewage and house hold garbage. Indian peafowl and grey francolin prefer shrub habitat with luxuriant growth of weeds enveloped by cultivated crops as they offer shelter and camouflage from mammalian predators. The present work seems reliant at local scale but has broad implication because of habitat association of village ponds and avian diversity applicable for Punjab plains.

\section{ACKNOWLEDGMENT}

The authors are thankful to the Head, Department of Zoology, Punjab Agricultural University, Ludhiana for providing necessary facilities to carry out this work. The authors are extremely grateful to Dr. Tarundeep Kaur (Assistant Agronomist) Department of Agronomy, Punjab Agricultural University for providing guidance in identification of weeds. This research did not receive any specific funding.

\section{Statement of conflict of interest}

The authors declare no conflicts of interest.

\section{REFERENCES}

Cereghino, R., Boix, D., Cauchie, H-M., Martens, K. and Oertli, B., 2014. The ecological role of ponds in a changing world. Hydrobiologia, 723: 1-6. https://doi.org/10.1007/s10750-013-1719-y

Chang, K.W. and Chang, C.Y., 2000. The relationship between landscape ecology structure and species diversity of birds. Hort. NCHU., 25: 95-108.

Fairchild, G.W., Anderson, J.N. and Velinsky, D.J., 2005. The trophic state 'chain of relationships' in ponds: Does size matter? Hydrobiologia, 539: 35 46. https://doi.org/10.1007/s10750-004-3083-4

Froneman, A., Mangnall, M.J., Little, R.M. and Crowe, T.M., 2001. Waterbird assemblages and associated habitat characteristics of farm ponds in the Western Cape, South Africa. Biodivers. Conserv., 10: 251270. https://doi.org/10.1023/A:1008904421948

Grimmett, R., Inskipp, C. and Inskipp, T., 2011. Birds of the Indian Subcontinent. Christopher Helm Publishing Company, London, U.K.

Huang, K.F., 2012. Function of farm pond, pool and detention pond. Technol. Soil Water Conserv., 7: 63-65.

Hunter, J.V., Jeske, C.W. and Norling, W., 2002. Managing agricultural wetlands for waterbirds in the coastal regions of Louisiana, USA. Waterbirds, 25 (Suppl. 2): 66-78.

Jha, K.K., 2013. Aquatic food plants and their consumer birds at Sandi Bird Sanctuary, Hardoi, Northern India. Asian J. Conserv. Biol., 2: 30-43.

Kler, T.K., 2002. Man-made threats to avifauna of village ponds/water bodies. Pestology, 26: 39-42.

Kumar, P., Rai, D. and Gupta, S.K., 2016. Weland bird assemblage in rural ponds of Kurukshetra, India. Waterbirds, 39: 86-98. https://doi. org/10.1675/063.039.0111

Lai, C., Lin, S., Tsai, C., Chen, S., 2018. Identifying farm pond habitat suitability for the common moorhen (Gallinula chloropus): A conservationperspective approach. Sustainability, 10: 1352. https://doi.org/10.3390/su10051352

Lu, A.H., Perng, J.J., Kuo, W.C., Ueh, C.L., Ting, C.S. and Chen, J.H., 2007. A biodiversity study on the rural ditch landscape in the Wuggo Village, Pingtung County. Taiwan J. Archit., 59: 163-188.

Ma, Z., Cai, Y., Li, B. and Chen, J., 2010. Managing wetland habitats for waterbirds: An international perspective. Wetlands, 30: 15-27. https://doi. org/10.1007/s13157-009-0001-6

Macro-Mendez, C., Prado, P., Ferrero-Vicente, L.M., Ibanez, C. and Sanchez-Lizaso, J.L., 2015. Seasonal effects of waterfowl grazing on submerged macrophytes: The role of flowers. Aquat. Bot., 120: 275-282. https://doi.org/10.1016/j. aquabot.2014.09.006

Mahesh, M., Krishnan, S.M. and Kannan, D.P., 2018. 
Interactive phenomenon of plants and avian diversity in Vettangudi Bird Sanctuary, Southern India. Sci. Int., 6: 65-70.

Manoj, K. and Padhy, P.K., 2015. Discourse and review of environmental quality of river bodies in India: An appraisal of physicochemical and biological parameters as indicators of water quality. Curr. World Environ., 10: 537-571. https://doi.org/10.12944/ CWE.10.2.20

Mishra, H., Kumar, V. and Kumar, A., 2019. Population structure and habitat utilization of migratory birds at Bakhira Bird Scantuary Uttar Pradesh, India. Pakistan J. Zool., 52: 247-254.

Miracle, M.R., Oertli, B., Céréghino, R. and Hull, A., 2010. Preface: Conservation of European pondscurrent knowledge and future needs. Limnetica, 29: 1-8.

Mohan, D. and Gaur, A., 2008. Avian diversity around Jajiwal Pond - A natural wetland. Proc. Taal, 2007: The 12th World Lake conference. pp. 542-546.

Nur, N., Jones, S.L. and Geupel, G.R., 1999. A statistical guide to data analysis of avian monitoring programs. U.S. Department of the Interior, Fish and Wildlife Service, BTP-R6001-1999, Washington, D. C.

Parveen, J., Jayapal, R., Pittie, A., 2016. A checklist of birds of India. Indian Birds, 11: 113-172.

Rajpar, M.N. and Zakaria, M., 2011. Effects of water level fluctuation on waterbirds distribution and aquatic vegetation composition at natural wetland reserve, Peninsular Malaysia. Int. Schol. Res. Netw., 2011: 1-13. https://doi.org/10.5402/2011/324038

Sebastián-González, E., Sánchez-Zapata, J.A. and Botella, F., 2010. Agricultural ponds as alternative habitat for waterbirds: Spatial and temporal patterns of abundance and management strategies. Eur. J. Wildl. Res., 56: 11-20. https://doi.org/10.1007/ s10344-009-0288-x

Sleeter, B.M., Sohl, T.L., Loveland, T.R., Auch, R.F., Acevedo, W., Drummond, M.A., Sayler, K.L. and Stehman, S.V., 2013. Land-cover change in the conterminous United States from 1973-2000. Glob. Environ. Chang., 23: 733-48.

Smith, S.V., Renwick, W.H., Bartley, J.D. and Buddemeier, R.W., 2002. Distribution and significance of small, artificial water bodies across the United States landscape. Sci. Total Environ., 299: 21-36. https:// doi.org/10.1016/S0048-9697(02)00222-X

Sony, S., Kler, T.K., Javed, M., 2019. Emerging threat of urbanization to ponds and avian fauna in Punjab, India. J. Ent. Zool. Stud., 7: 1310-1315.

Verner, J., 1985. Assessment of counting techniques. Curr. Ornithol., 2: 247-302. https://doi.org/10.1007/9781-4613-2385-3_8 